\title{
S1630107
}

\section{EEG 信号を用いたリアルタイム動作推定に関する研究}

林 喜章*1, 木口 量夫 ${ }^{* 2}$

\author{
A Study of Motion Estimation Method Based on EEG Signals \\ Yoshiaki HAYASHI $^{* 1}$ and Kazuo KIGUCHI \\ ${ }^{* 1}$ Saga Univ. Dept. of Advanced Technology Fusion \\ Honjo-machi 1, Saga-shi, Saga, 840-8502 Japan
}

In recent years, an electroencephalogram (EEG) signal that is measured along a scalp is used as input signal for various robots. In the case of wearable robots, an EMG signal is often used for input signal. Compared with EMG signals, the advantage of EEG signals is that EEG signals are able to be measured from more persons. However, it is more difficult to estimate a user's motion intention from EEG signals than EMG signals. The purpose of this study is to estimate a user's motion intention from EEG signals in order to control a wearable robot. In this paper, we discuss the learning method of the EEG-based estimation method for combined motions of shoulder and elbow joints.

Key Words : EEG signals, Motion estimation

\section{1. 緒}

ウェアラブルロボットを使用者の意図通りに制御するために用いられる入力信号の一つに筋電信号がある， ロ ボットでアシストする関節を駆動する筋肉から筋電信号を計測することでその関節の動作を推定することができ る(1). また，近年では，頭皮上に配置した電極から計測する脳波信号（EEG 信号）を用いてロボットを制御する 研究もおこなわれている(2). 筋電信号を用いるシステムの場合, 事故等により肢を失った人など, 制御に必要な 筋電信号を必ずしも計測できるとは限らないため, 使用者が限定される恐れがある. 一方, EEG 信号を用いたシ ステムでは，基本的に使用者を限定しない利用が期待できる.

そこで，本研究では EEG 信号を用いてウェアラブルロボットを使用者の意図通りに制御するために，EEG 信 号から使用者の動作意図の推定を試みている ${ }^{(3)}$. 本稿では, 肩関節及び肘関節の屈曲・伸展運動を EEG 信号から 推定することを試みる.

\section{2. 功作推定}

本稿では, 国際 10-20 法に従って配置した電極を用いて EEG 信号を計測し, 計測された EEG 信号を用いて肩, 肘関節の角速度の方向と大きさを推定する. 回転方向を推定するために, 計測された EEG 信号に $4 \mathrm{~Hz}$ のローパ スフィルタをかけ, フィルタ後の信号を入力とするシグモイド関数に代入し，チャンネルごとに閾值を超えてい るかを確認する. この組み合わせにより回転方向を推定する. 各チャンネルの閾值, 組み合わせは事前実験によ り決定する. 一方, 角速度の大きさは式（1）を用いて推定する.

$$
\dot{\theta}_{k}(t)=\sum_{i=1}^{N_{c h}} w_{k i} \cdot e_{i}(t)
$$

\footnotetext{
“1 正員, 佐賀大学 (厂840-8502 佐賀県佐賀市本庄町 1)

*2 正員, 九州大学 (广819-0395 福岡県福岡市西区元岡 744)

E-mail: hayashi@me.saga-u.ac.jp
} 


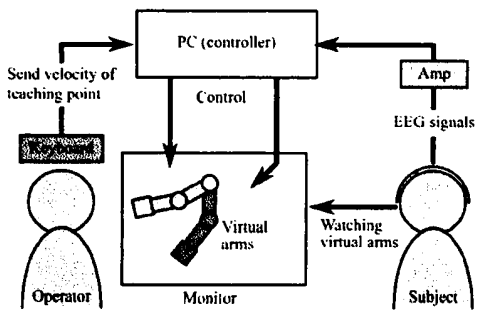

Fig. 1 Outline of experiment.

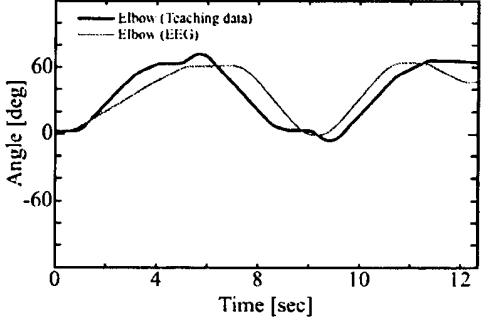

Fig. 2 Experimental results.

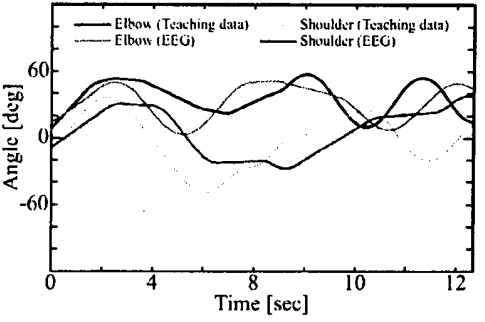

Fig. 3 Experimental results. (Shoulder and Elbow motion)

式 (1) において, $\theta_{k}(t)(k=s, e)$ は肩関節及び肘関節の角度, $e_{i}(t)$ はフィルタリング後の EEG 信号, $w_{k}$ はウ エイト值である. ウエイト值は下記（2）式で求める.

$$
w_{k i}=w_{Z E, k i} \cdot f i t_{Z E, k i}+w_{P S, k i} \cdot f i t_{P S, k i}+w_{P B, k i} \cdot f i t_{P B, k i}
$$

ここで $w_{j, k i}(j=Z E, P S, P B)$ は各メンバーシップ関数におけるウエイト值, $f i t_{j, k}$ はメンバーシップ関数の適合 度である. $w_{j, k i}$ は誤差逆伝播法を用いて更新する.

\section{3. 县作推定实験}

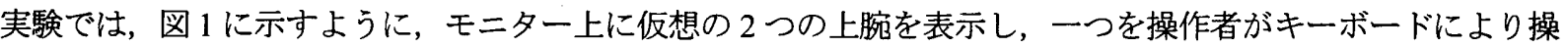
作し, もう一つを被験者の EEG 信号を用いて操作する. 本稿では, 肩もしくは肘関節のどちらか一つの関節に着 目し, 関節ごとにウエイト值の学習を行う場合と, はじめから 2 関節同時に学習する場合の 2 つの方法で実験を 行った. 実験結果を図 2,3 に示す. 図 2 は肘関節のみを動かし学習を行った場合の実験結果である. 黒い実線は 操作者が操作した教示データ, 赤い実線は EEG 信号から推定した角速度から算出した肘関節角度である. 図 2 に示すように EEG 信号から単関節の角速度を推定できていることが確認できる. しかしながら, 有関節および 时関節，それぞれの単関節の学習を行った後，2関節を同時に推定することを試みたが，操作者の動作に追従し て推定することができなかった．一方，図 3 は 2 関節同時に学習した場合の結果である. 緑の実線は操作者が操 作した肩関節の教示データ，青い実線は EEG 信号から推定した角速度から算出した肩関節角度である. 本実験の 結果から, 単関節の動作をそれぞれ学習した場合と比較して，2 関節同時に学習した方が，操作者の示した動作 により追従できることが確認できた.

\section{4. 結 语}

本稿では EEG 信号を用いて肘関節および肩関節の動作推定を試みた. 各関節の回転方向と，その速度の大きさ をそれぞれ推定し，学習によりパラメータを調整した．実験により単純な単関節動作の学習では, 多関節の複合 動作に対応できないこと，複合動作を想定した学習により操作者が示した動作に追従する精度が向上することが 確認できた.

\section{文献}

(1) C.J.Yang, J.F. Zhang,Y. Chen,Y.M. Dong, andY. Zhang, "A review of exoskeleton-type systems and their key technologies", Proc. of IMechE, Journal of Mechanical Engineering Science, Part C, Vol.222 (2008), pp.1599-1612.

(2) F. Lotte, M. Congedo, A. Lecuyer, F. Lamarche, and B. Arnaldi, "A review of classification algorithms for EEG-based brain-computer interface", Journal of Neural Engineering, Vol. 4 (2007).

(3) C.J.Yang, J.F. Zhang,Y. Chen,Y.M. Dong, andY. Zhang, "A review of exoskeleton-type systems and their key technologies", Proc. of IMechE, Journal of Mechanical Engineering Science, Part C, Vol.222 (2008), pp.1599-1612.

(4) 林喜章, 山口翔, 木口量夫, “ウェアラブルロボット制御における EEG 信号処理に関する考察”, 日本機械学会 2013 年度年次大会, (2013), S163013. 